\section{Mind the Gap: Addressing Childcare Inequalities for Children and Caregivers}

JULIANA PINTO MCKEEN

SHE/HER
MIND THE GAP: ADDRESSING CHILDCARE INEQUALITIES FOR CHILDREN AND CAREGIVERS

Formal childcare in the United States has been in crisis since its inception. Maternal employment is heavily moralized, affecting the way that childcare is prioritized. Policies delineate clear lines between groups regarding which mothers should and should not work, with Black mothers and other mothers of color being denied the same benefits and protections as white mothers. Black mothers have been working in the United States since they were enslaved (Dow, 2014). After Black Americans were freed, Black mothers continued to work outside the home, often raising white children. Because they were working and could not rear their own children, they leaned on community care for their children. Examples of such community care providers include Black caregivers, housekeepers, wet nurses, and caretakers across history. While widow's pensions, a product of the Progressive Era, were instated to enable white mothers to stay home and care for their children, Black mothers were denied access to these funds and this policy with the justification that they had been working and therefore "should not be encouraged to stay at home to rear their children" (Michel, 2011).

Black women had to work because Black people in America made less money for their labor than white people, a disparity that continues today. While white families could generally live off of the income from one adult, Black families were forced to make ends meet with multiple employed adults. As bell hooks writes, "[B]lack women in the U.S. have always worked outside the home ... That work gave meager financial compensation and often interfered with or prevented effective parenting" (hooks, 2015, p. 133). Additionally, Black families were denied the generational wealth owed to them because of slavery and institutional racism. This racism is clear in instances where Black mothers were widowed and not afforded the same benefits under federal policy as white women.

For generations, Black families relied on community care, or fictive kin care, for their children. Examples of such care include older and younger generations within the same family taking care of children, as 
well as neighbors and friends, or mothers taking children to work, while workers take turns watching the children or everyone keeps an eye on them while labor continues. Fictive kin care was a form of mutual aid and a "normative response to limited economic opportunity" (MillerCribbs \& Farber, 2008, p. 45). Prior to childcare becoming regulated, and continuing to the present day, fictive kin care was often the only available option for Black families, families of color, and other low-income groups who relied on the financial support of maternal employment.

Since middle- and low-income white women joined the formal workforce, the discussion around the state's role in childcare has grown. The industry has been in crisis because the United States has not definitively decided whether or not white mothers should work outside the home. A long debate regarding the employment of white mothers, who are often portrayed as selfish if they do work (Michel, 2011 ), continues today and reflects the undervaluing of childcare in our society. Black mothers and other mothers of color continue to experience financial and familial ramifications of generations of racist policies as politicians and the court of public opinion deliberate.

While all parents and guardians are affected by the current state of childcare, this paper centers the experiences of mothers, especially Black mothers and other mothers of color, who are most impacted by lack of access to childcare. The compounding forms of inequality experienced by women of color are pivotal to consider and mitigate. By centering the needs and experiences of Black women and their children, the United States has an opportunity to create impactful childcare policies that benefit all.

\section{HISTORY OF CHILDCARE IN THE UNITED STATES}

As Michel (2011) explains, childcare in the United States has seen several iterations since the Progressive Era, 1897-1920. As womens' reforms gained traction, the nation began to discuss childcare. The first nurseries in the country were created by philanthropists and were privately funded through donations. The United States Children's Bureau was created in 1912 and advocated for mothers' pensions, which kept single mothers at home, solidifying the gender roles of the time. The purpose of these pensions was to enable widows and divorced mothers to "raise their children properly by staying at home" (Abramovitz, 2017, p. 140). The concept of traditional motherhood was seen as patriotic, sometimes compared to the sacrifice of soldiers.

Black mothers were denied access to these pensions due to institutional racism and continued to work outside the home. As Dow (2014) states, "[a]lthough these policies generally only reduced, rather than eliminated, a poor woman's need to work, these pensions underscored that, under ideal circumstances, white mothers should focus on their domestic duties" (p. 38). The concept of pensions was far more popular than the idea of creating childcare programs.

Ward (2005) states, "Political support and motivation for mothers' pensions was grounded not only on the sexist division of labor but on racial discrimination" (p. 50). The birth rate for native-born white children decreased from the nineteenth to twentieth century, coinciding with a large influx of immigrants to the United States. Pensions served the ulterior motive of safeguarding the white middle- and upper-class by ensuring that mothers could focus on mothering, thereby increasing the number of native-born white children.

In the 1920s, the lack of childcare created hazards for children and families, as parents were forced to take children to unsafe work environments or leave them unattended in order to work. Despite documented cases and the rising national problem, the Children's Bureau continued to advocate for pensions over childcare because of the patriarchal notion that women needed to be in the home in order to raise healthy children (Abramovitz, 2017). Experts argued that working mothers were bad for children's development, but they continued to have no issues with Black mothers working outside the home (Michel, 2011). The intersectionality (Krenshaw, 2015) of being mothers and Black women disqualified them from advances in policy.

World War II saw an increase in childcare programs as 6.5 million women entered the workforce (Hartmann, 1998). In 1934, The New Deal established Emergency Nursery Schools, which were partial day programs that operated free of cost to parents. Educators began 
to consider early childhood pedagogy. While programs operated as childcare, they were designed as schools. By focusing on the benefits of pedagogy for childhood development, creators of these programs were able to sidestep the conversation around women's right to work (Michel, 1999). Much like today, these programs were underfunded and had high staff turnaround, as educators became frustrated with the lack of resources and low wages (Michel, 2011).

The Lanham Act of 1943 approved federal funds for childcareto this day the only federal law establishing a national childcare program (Ertman, 2019). The investment was insufficient: by federal standards, there should have been one childcare slot for every ten female defense workers. However, as Michel explains, "when the female labor force peaked at 19 million in 1944, only 3,000 child care centers were operating, with a capacity for 130,000 children - far short of the 2 million places that were theoretically needed" (Michel, 2011). Additionally, many programs failed to meet quality and safety standards. Working mothers continued to be viewed as selfish by both society and the government, even as they supplied vital support to the war effort. After the war, the Truman administration cut funding for childcare established under the Lanham Act, as this funding was explicitly tied to wartime needs. Childcare programs were forced to close (Ertman, 2019). The Lanham Act benefitted white mothers and their children, but failed to provide services for Black mothers and families.

The federal government introduced the childcare tax reduction in 1954, offering working families in the formal work force financial relief of childcare costs via a maximum $\$ 600$ deduction in federal taxes (Buehler, 1998). Adults not in the formal work force did not receive this deduction: domestic workers, handy persons, and those performing forms of employment considered on-call or at-will were excluded. Additionally, the act did nothing about "the supply, distribution, affordability, and quality of child care" (Michel, 2011). The late 1950s saw the emergence of advocacy groups that continued to push for the creation of childcare programs. The Inter-City Committee for Day Care of Children believed that childcare should be provided by the government instead of private charity. They worked with government agencies to make this a reality by gaining federal support for publicly funded childcare (Michel, 2011).

President Kennedy's President's Commission on the Status of Women (PCSW), created in 1961, signaled the federal government's willingness to discuss maternal employment and considered the developmental attributes of childcare, as well as its opportunity to advance integration. As opposed to previous policies that left out Black and Brown ${ }^{1}$ Americans, the PCSW introduced the possibility of serving a representative "cross section" of the population for the benefit of "democratic social development" (Front Matter, 1963).

Subsequent administrations, such as Nixon's, only supported childcare efforts for low-income families, curtailing advocacy efforts while continuing to provide tax incentives to employers and middle- and upperclass families. The Reagan era saw far reaching cuts to welfare for lowincome families, while expenditures for middle- and high-income families nearly doubled. These economic policies forced the childcare system to shift to for-profit models.

The 1990s brought large investments in childcare via the Child Care and Development Fund (CCDF), but as before, these funds lacked supply and quality. This fund continues to be the main source of government investment in childcare, practically applied by allowing states "significant freedom to coordinate the child care support for low-income families in their state" (Vesely \& Anderson, 2009, p. 41). Childcare costs continued to rise, while tax credits did not. The CGDF was created in part as a response to the racialized idea of the "welfare queen" perpetuated by the Reagan administration and exacerbated by Clinton. These administrations were responsible for upholding this myth and exploiting "popular welfare racist attitudes that were well documented by polling and other data" (Doran \& Roberts, 2002, p. 402). New policies required proof of work in order to receive benefits, but did not take into account the impact of systemic racism in families' ability to enter the formal

1 This paper recognizes that labels and organizations of race and ethnicity cannot fully capture the myriad of racial and ethnic identities and lived experiences. The paper uses the following labels: Black, Brown, and white. The term "Brown" is used to refer to non-Black people of color.

COLUMBIA SOCIAL WORK REVIEW, VOL. XIX 
labor market. Politicians did not foresee that the childcare industry would become highly represented by Black and Brown women who are unable to afford the same care for their children that they provide for others.

\section{WAGES AND LACK OF PAY PARITY BETWEEN TEACHERS AND CHILDCARE WORKERS}

Although childcare costs are rising for programs and consequently for families, workers' wages are not. Operating costs have a direct impact on the price point for enrolled families. While regulations and costs vary by state, costs largely include liability insurances, supplies, venue, food costs, and payroll. Programs are required to hire the appropriate number of staff based upon the ages of the children served and state-mandated ratios of children to staff. Costs also vary depending on geography. Programs in urban areas cost more to operate than those in rural areas. On average, childcare workers nationwide make $\$ 24,600$ per year less than K-12 teachers per year (Interlandi, 2018).

The issue of pay parity is at the forefront of advocacy in New York State, as childcare workers in Department of Education funded programs need to meet the same requirements as K-12 teachers but make a fraction of the income. The majority of grade school teachers are white women, while approximately $45 \%$ of childcare workers are Black, Latinx, or Asian and are grossly underpaid for their labor (Mueller, 2020). Activist groups continuously demand more funding for subsidies and pay parity between childcare educators and childcare providers. These two professions are often compared and presented as antagonists, with childcare providers seen as inferior and paid as such. For example, in New York City, both early childhood educators working in programs licensed under Article 47 of the health code and grade school teachers require a master's degree and a state teaching certification. However, early childhood educators in New York City earn on average $\$ 20,000$ less per year (Krien \& Mason, 2019). This could be in large part because grade school relies on sizable government investment, while early childhood relies upon families to foot the bill.

Lack of wage theft regulation further compounds the problem.
Childcare is not a profession that you can truly clock out from when your workday is over. If there are children left to watch, you cannot leave them alone. However, a lot of programs do not have overtime pay. While workplace protections do cover childcare workers, nonpayment for labor is commonplace. Some programs are so small, serving less than twenty families, that they operate under the radar of regulators. Childcare operators find themselves in a difficult position, wanting to pay their employees for their work, but knowing this would increase operating costs, which might cause a decrease in enrollment due to families seeking cheaper alternatives. If a program does not take private pay and only uses subsidies and vouchers, it is not their prerogative to offer overtime pay.

Calls to action on childcare exist, but have lacked pivotal investments. In 2019, the Child Care for Working Families Act was introduced, which would provide funds for the Child Care and Development Block Grant and revise it to "create a tiered and transparent system... [and] assure that copayments are based on a sliding scale," among other improvements (Child Care For Working Families Act, 2019). Childcare champions do exist, such as Senator Elizabeth Warren and Representative Rosa DeLauro, among others. This past July, the Childcare Is Essential Act passed in the House but has not made it to the Senate floor. The bill called for $\$ 50$ billion in federal funding for childcare (Childcare Is Essential Act, 2020). The Biden administration released a plan for childcare as part of their coronavirus rescue package. In this plan, the administration proposes creating a $\$ 25$ billion stabilization fund to support programs in danger of closing permanently, invest an additional $\$ 15$ billion in the Child Care and Development Block Grant program, and increase tax credits to cover the costs of childcare (Fox, 2021). These efforts do not address the pay disparity in the industry, but they work to create stability and financial aid for families. The issue of low wages and lack of pay parity coincides with the representation of workers in these industries. The racial makeup of these workers is historically commensurate with the pay they receive, continuing to uphold systems of inequity and oppression. 


\section{CHILDCARE AND SOCIAL ISSUES}

Childcare continues to be a pain point for families across the nation, even as an estimated 51\% of women were in the workforce in 2016 according to the Department of Labor (US Department of Labor, n.d.). Large parts of the childcare system are operated as businesses because government funding is finite, leaving families to pay out of pocket and childcare programs to compete for clientele. A report by the Economic Policy Institute found that in 2019, public spending on childcare and early childhood education totaled about $\$ 34$ billion, while household spending totaled about $\$ 42$ billion (Gould \& Blair, 2020). The expense creates a push and pull between families and programs; programs constantly attempt to keep costs low for families and are thus unable to pay educators a fair wage. Childcare costs vary from state to state and have been rising in recent years. For example, the cost of childcare for an infant in Mississippi is $\$ 453$ per month, versus $\$ 1,412$ in California (Economic Policy Institute, 2020). Across the board, childcare workers are underpaid, with an average annual income of $\$ 28,000$ per year, and only 15\% have access to healthcare through their employers (Interlandi, 2018).

The issue of fair pay overwhelmingly affects Black and Brown women, who make up $45 \%$ of childcare workers. Much like in previous generations, disadvantaged women take care of other people's children, while their own children are denied this level of care. Many childcare workers cannot afford to send their children to the same programs that employ them. Generations of inequitable policies have forced two divergent options: upper- and middle class families can send their children to early childhood programs designed to kickstart education using a myriad of different pedagogies and modalities, while lower-class families must rely on a social welfare system to help take care of their kids at sometimes questionable standards. This dynamic introduces another point of intersectionality: socioeconomic status. These options for care of very young children often fall along racial lines, with Black and Brown families most often being forced to utilize the second option. These two modes of care falsely separate care and education, while the two are inextricably linked. Early education teachers indisputably care for their students, and childcare providers undoubtedly educate the children for whom they provide care. This separation serves to drive a wedge between the professions and upholds pay discrepancies.

A solution to disparities in care and education between racial groups and economic classes requires deep investments and culturally relevant pedagogies. The childcare industry is an afterthought in policy and financial decisions. This causes adverse consequences to children, families, and childcare providers. Our society has not eradicated this problem because it is perceived as a women's problem and a problem of low socioeconomic status, thus low priority. At its core, the trivializing of childcare in the United States is a sexist and racist societal policy. History and policies have shown that the nation has decided white mothers should remain at home and Black and Brown mothers should work (Miller, 2019). Quality early childhood education affords children great benefits long into adulthood and is a vehicle for upward mobility, but because many white families can afford childcare, policy makers have not been pushed to find a solution. Early childhood education allows adults in the family to work outside the home if willing and able. It is a venue to help children develop their social skills, growing bodies, and to begin to acclimate to academic environments. The childcare system was unjustly created with white families in mind and continues to suit only their needs.

\section{CHILDCARE POLICIES}

Even well-intended broad policy attempts to regulate childcare, an industry that has community-dependent cultural implications, have had negative consequences. Generally, the federal government provides minimal funds, via the Child Care and Development Block Grant, to states to regulate how they see fit. States enact sweeping regulations that dictate which programs and families receive funding. Within states, there are vast differences between communities and jurisdictions. Broad rules do not have equal effects on all participants of the system, in the same way that one curriculum does not suit the needs of all children. The childcare system today is a result of disjointed funding and regulations that do not put children, families, and caregivers at the center. Policies 
have failed because they fragment the system and allocate insufficient funds.

On a micro level, there is a significant impact on children and families. Supply issues in parts of the country render quality programs hard to come by. Regulations meant to assure a standard of care often increase red tape and create barriers to entry for prospective childcare providers. Calls for reform and for early education programs that also serve as childcare, like Pre-K for All, are good starts. However, because the system is fragmented, they often complicate operations for providers and continuously leave some behind.

For example, since New York City implemented the Universal Pre-K program in 2014 many more children entered early childhood programs. This is beneficial to both the children and their families. Pitfalls include the oversight by an additional agency, the Department of Education, to regulate programs previously only regulated by the Department of Health. Sometimes these agencies have different regulations and both expect providers to meet their regulations, even at the cost of a citation from the other. In practice, this labyrinthine structure means that depending on which agency arrives for an inspection, providers can receive citations and fees for being out of compliance with one agency while abiding by the rules of another.

For New York City children younger than four, families can receive subsidies they can use to pay for childcare. Effectiveness of subsidies is reliant on state and local regulations. Often, programs who accept subsidies are forced to accept less financial recompense for their service and/or be paid much later than the service was provided. Programs that accept subsidies may choose to do so to serve their communities, if families require this aid. When the system works at its best, providers can depend on consistent payment from subsidies. Subsidy payments require maneuvering bureaucracy and paperwork that not all programs have the bandwidth or knowledge to do. Often, subsidies are more beneficial to families than providers (Adams \& Snyder, 2003).

On a macro level, there are severe consequences to the wellbeing and social mobility of large swaths of children in our nation. The lack of access to quality early childhood education and childcare for all has economic repercussions for children long into adulthood, for parents-most often mothers--and for childcare providers. Access to early childhood education affords children wellbeing and economic gains long after they have graduated from these programs. Working mothers are good for our country and for mothers themselves. Longitudinal studies have found that mothers' continuous and full time employment is correlated with significantly better mental and physical health at age 40 than mothers who were unemployed, non-continuously employed, or not employed full time (Frech \& Damaske, 2012). As discussed above, childcare workers are underpaid and as such, unable to experience social mobility themselves, continuing the cycle of inequality within their families and communities.

Additionally, communities often try to create other venues to provide childcare to those in need, such as legally exempt providers or unlicensed childcare groups. These types of programs mimic community care of past generations. Low-income communities attempt to circumvent the regulations because compliance is often cost prohibitive to families and providers alike. Licensing a program can take months of navigating ever-changing regulations. Barriers to entry include the lack of capital funds, mandated education, and social capital. A lack of research exists on this demographic, perhaps in part due to the potential repercussions of operating an unlicensed program. Childcare policies aimed at regulating funding and formalizing care impede some caregivers from providing care in legal ways. Childcare policies should suit the needs of communities, as opposed to forcing communities to conform to policies that prevent adequate care.

\section{ANTI-RACIST APPROACH TO CHILDCARE: RETHINKING EARLY CHILDHOOD EDUCATION}

Quality early childhood care and education are great vehicles of upward mobility. Longitudinal studies show that children who attended early childhood education programs were less likely to become teenage parents, more likely to graduate high school, and more likely to enroll in higher education. In some instances, adults who attended one of these 
programs had higher median incomes, were less likely to be on welfare, and were less likely to have been arrested (Interlandi, 2018). Investments in children's education, health, and wellbeing are generational investments; the government tends to receive a return on investment with additional capital gains (Hendren \& Sprung-Keyser, 2020). As the authors of these studies explain, investments in children have historically yielded the largest Marginal Value of Public Funds, meaning that the policies pay for themselves over time and actually produce money. Equitable access to childcare would be a wise, anti-racist policy that would greatly impact the nation.

An anti-racist approach to solving the issues documented here would be to craft a new system that places the child at the center, values childcare providers and educators, listens to them in the creation of a system, and places a hefty investment in such a system. By redressing past injustices, such as inequalities in access to care and financial aid to Black and Brown mothers, meeting the needs of children and families of color, supporting the whole family, and serving all children and families in need (Minoff et al, 2020), policymakers and advocates can implement antiracist policies. All families and children should have access to childcare and early childhood education and to the myriad of pedagogies to best suit the child. By creating a system that does center children, families would have options. This is important because the solution is a not a cookie cutter curriculum for all childcare programs and looks different depending on the child, the family, and the community.

There are beautiful models of what this could look like: Afrocentric Montessori programs, bilingual Reggio Emilia programs, and a Lakota Waldorf school. Children have individual needs and learn better using different modalities. Programs that make whole families feel welcome are better suited to meet these needs. The system currently in place was created solely with white families in mind. New policies should support efforts to create culturally relevant early childhood programs that are reflective of the communities they serve. With significant and continuous investment, we can pay childcare providers the wages they deserve.

Childcare should be accessible to everyone and should be seen as the public good it really is (University of California, Berkeley, 2018). After all, childcare allows parents to stimulate our economy and safeguards our future: children.

\section{CHILDCARE AND THE COVID-19 PANDEMIC}

The pandemic has gravely exacerbated the pitfalls of the childcare system. In July 2020, the National Association for the Education of Young Children (NAEYG) (2020) completed a survey and estimated that $40 \%$ of all early childhood education programs would close their doors before the end of the year without government help (Beer, 2020). The CARES Act earmarked a pittance for the struggling industry and made the disbursement at each state's discretion. Although it has never been fully funded by the public, the childcare industry costs around $\$ 10$ billion per month. The GARES Act earmarked $\$ 3.5$ billion total for childcare (Bedrick \& Daily, 2020). The pandemic has decimated the childcare industry, with programs closing daily. A December 2020 survey by NAEYG found that approximately $42 \%$ of programs that have permanently closed due to the pandemic were minority-owned (NAEYG, 2020). In New York State, providers continue to wait for the remaining CARES Act funding that has yet to be disbursed while programs suffer.

This existential crisis has pushed industry, legislators, and activists alike to action. The Child Care is Essential Act was a good start. This bill would have created a Child Care Stabilization Fund with $\$ 50$ billion to offset the repercussions of the COVID-19 pandemic on the industry (Child Care is Essential Act, 2020). Seeing a bill of that magnitude pass in the House was a momentous event. Senator Elizabeth Warren advocated for childcare on the campaign trail during her bid for the presidency and again during the 2020 Democratic National Convention. Childcare has entered the national conversation. In response to the effects of the COVID-19 pandemic, an exponential number of articles have been written by journalists, economists, pedagogues, and sociologists. Topics include the effects of isolation on children, the effects of a lack of childcare on women in the workforce, and the disproportionate harm to an entire sector of the economy. Folks have seen and felt what is to be 
without childcare. As families sheltered in their homes for a year, there was a refreshed awareness of the importance of childcare. Now, we must use the catalyst that was 2020 to create lasting changes for childcare.

A COVID-19 stimulus package signed into law in March 2021 included a large benefit to children nationwide: a large expansion to the existing child tax credit, which will benefit $93 \%$ of children nationwide (DeParle, 2021). This new law includes provisions that will cut the child poverty rate in half and have an even bigger impact for Black children (Barbaro, 2021). Families will receive monthly checks of up to $\$ 300$ per child, regardless of the number of children in the family without negating other benefits families receive. The benefit diminishes only when families earn over $\$ 150,000$ annually. There are no specifications for the ways families can choose to spend these funds. This type of welfare is revolutionary in the United States after the devastating effects of the "welfare queen" myth and the institution of aid contingent on parental employment. The child tax credit is directly tied to the child, as opposed to the guardian, whose actions will have no bearing on the funds. The stimulus package institutes this expansion for one year, after which its extension will require Congressional action.

\section{CONCLUSION}

Childcare is a heavily moralized but vital service in the United States, and the inadequacy of childcare is intrinsically tied to race and class. Formal and regulated childcare began in the public realm, was created for white families, and was funded by the government to support war efforts. A lack of necessary funding to childcare programs pushed the industry to privatization, which widened the inequities between white families and all other families. Attempts to publicly fund childcare and early childhood education were seen as opportunities to integrate in the 1960s, but failed to meet this goal. In 2021, inequalities still exist in care between Black and Brown families and white families. The COVID-19 pandemic has widened this gap and concurrently proven the worth of the industry. The March 2021 expansion of the child tax credit is a viable option for combating childhood poverty and simultaneously stabilizing childcare. The nation has an opportunity to reimagine a system that serves our present and our future. Failure to capitalize on this opportunity will further metastasize the generations-long impacts of inequality. The United States can ill-afford to continue to ignore the fact that early childhood education and childcare should serve and be accessible to all families and children.

\section{REFERENCES}

Abramovitz, M. (2017). Regulating the lives of women: Social welfare policy from colonial times to the present (3rd ed.). Routledge. https://doi-org.ezproxy.cul. columbia.edu/10.4324/9781315228150

Adams, G., \& Snyder, K. (2003, February). Child care subsidy policies and practices:

Implications for child care providers (Policy brief Series A, No. A-57). The Urban Institute. https://www.urban.org/research/publication/child-care-subsidy-policiesand-practices

Barbaro, M. (Host). (2021, March 9). A safety net for American children [Audio podcast episode]. In The Daily. The New York Times. https://www.nytimes. com/2021/03/09/podcasts/the-daily/economic-stimulus-child-tax-credit.html

Bedrick, E., \& Daily, S. (2020, June 8). States are using the CARES Act to improve child care access during COVID-19. Child Trends [Policy brief]. https://www.childtrends. $\mathrm{org} /$ publications/states are-using-the-cares-act-to-improve-child-care-access-duringcovid-19

Beer, T. (2020, July 15). 40\% of U.S. child care centers say they'll close permanently without public assistance. Forbes. https://www.forbes.com/sites/ tommybeer/2020/07/14/40-of-us-child-care-centers-say-theyll-close-permanentlywithout-public-assistance/?sh=240eef8e6ad6

Buehler, S. J. (1998). Child care tax credits, the child tax credit, and the taxpayer relief act of 1997: Congress' missed opportunity to provide parents needed relief from the astronomical costs of child care. Hastings Women's Law Journal, 9(2), 189-218.

Child Care For Working Families Act, H.R.1364, 116th Cong. (2019). (U.S.). https:// www.congress.gov/bill/116th-congress/house-bill/1364/text

Child Care Is Essential Act, H.R.7027, 116th Cong. (2020). (U.S.). https://www.congress. gov/bill/116th-congress/house-bill/7027

Deparle, J. (2021, March 07). In the stimulus bill, a policy revolution in aid for children. The New York Times. https://www.nytimes.com/2021/03/07/us/politics/child-taxcredit-stimulus.html

Doran, M., \& Roberts, D. E. (2002). Welfare reform and families in the child welfare system. Maryland Law Review, 61(2), 386-436.

Dow, D. (2014). Negotiating "The welfare queen" and "The strong Black woman": African American middle-class mothers' work and family perspectives. Sociological 
Perspectives, 58(1), 36-55. https://doi.org/10.1177/0731121414556546

Economic Policy Institute. (2020). Child care costs in the United States. https://www.epi. $\mathrm{org} /$ child-care-costs-in-the-united-states/

Ertman, T. (2019, June 27). The Lanham Act and universal childcare during World War II. Friends of the National WWII Memorial. https://www.wwiimemorialfriends.org/ blog/wwii-universal-childcare/

Fox, M. (2021, January 15). Biden pledges to help fix the child-care crisis in America. Here is his plan. CNBC. https://www.cnbc.com/2021/01/15/biden-has-a-plan-tohelp-fix-the-child-care-crisis-in-america.html

Frech, A., \& Damaske, S. (2012). The relationships between mothers' work pathways and physical and mental health. Journal of Health and Social Behavior, 53(4), 396-412. http://www.jstor.org/stable/41725228

Front Matter. (1963). In American women: Report of the president's commission on the status of women, 1963 (pp. 1-12). District of Columbia: United States. Government Printing Office. Women and Social Movements in the United States, 1600-2000 database.

Gould, E., \& Blair, H. (2020, January 15). Who's paying now? The explicit and implicit costs of the current early care and education system. Economic Policy Institute. https://files.epi.org/pdf/181729.pdf

Krenshaw, K. (2015, Sept 24). Why intersectionality can't wait. The Washington Post.

https://www.washingtonpost.com/news/in-theory/wp/2015/09/24/whyintersectionality-cant-wait/

Krien, T., \& Mason, M. (2019, July 31). Salary parity explained. The Child Center of NY. https://childcenterny.org/salary-parity-explained/

Hartmann, S. M. (1998). Home front and beyond: American women in the 1940s. Twayne Publishing.

Hendren, N., \& Sprung-Keyser, B. (2020). A unified welfare analysis of government policies. The Quarterly Journal of Economics, 135(3), 1209-1318. https://doi. org/10.1093/qje/qjaa006

hooks, b. (2015). Feminist theory: From margin to center. Routledge.

Interlandi, J. (2018, January 9). Why are our most important teachers paid the least? The New York Times. https://www.nytimes.com/2018/01/09/magazine/why-are-ourmost-important-teachers-paid-the-least.html

Michel, S. (1999). Children's interests/mothers' Rights : The shaping of America's child care policy. Yale University Press.

Michel, S. (2011). The history of child care in the U.S. Social Welfare History Project.

http://socialwelfare.library.vcu.edu/programs/child-care-the-american-history/

Miller, C. C. (2019, August 15). Why the U.S. has long resisted universal child care. The New York Times. https://www.nytimes.com/2019/08/15/upshot/why-americansresist-child-care.html
Miller-Cribbs, J., \& Farber, N. (2008). Kin networks and poverty among African Americans: Past and present. Social Work, 53(1), 43-51. http://www.jstor.org/ stable/23721188

Minoff, Elisa et al. (2020). Principles for anti-racist policymaking. Center for the Study of Social Policy. http://bit.ly/Anti-Racist-Policymaking

Mueller, E. (2020, July 22). 'Crashing down': How the child care crisis is magnifying racial disparities. Politico. https://www.politico.com/news/2020/07/22/coronavirus-childcare-racial-disparities-377058

National Association for the Education of the Young Child. (2020). Am I next? Sacrificing to stay open, child care providers face a bleak future without relief. https://www. naeyc.org/sites/default/files/globally-shared/downloads/PDFs/our-work/publicpolicy-advocacy/naeyc_policy_crisis_coronavirus_december_survey_data.pdf

University of California, Berkeley. (2018). (rep.). Early childhood workforce index: About the early childhood workforce. https://cscce.berkeley.edu/early-childhood-workforce2018-index/

US Department of Labor: Women's Bureau. (n.d.).Women of working age. https://www. dol.gov/agencies/wb/data/latest-annual-data/working women.

Vesely, C. K., \& Anderson, E. A. (2009). Child care and development fund: Policy analysis. Journal of Sociology and Social Welfare, 36(1), 39-60.

Ward, D. (2005). The white welfare state: The racialization of U.S. welfare policy. Ann Arbor: University of Michigan Press. doi:10.3998/mpub.22210

JULIANA PINTO MCKEEN (she/her) is a Masters of Science in Social Work candidate at Columbia School of Social Work in Advanced Generalist Practice and Programming track concentrating in Contemporary Social Issues. Juliana holds a Bachelor of Science in Psychology and a minor in African American, Puerto Rican and Latino Studies from Hunter College. Prior to matriculating at Columbia she co-founded and directed a small early childhood education program. Juliana currently works as a Social Work Intern at the Legal Aid Society's New York Immigrant Family Unity Project. She serves on the Waldorf Early Childhood Association of North America's Inclusion, Diversity, Equity, and Access committee and is a founding member and the administrator for the Brooklyn Coalition of Early Childhood Programs. Originally from Bogotá, Colombia, Juliana now lives in Brooklyn, New York. 